\title{
O Que Quer Uma Professora?
}

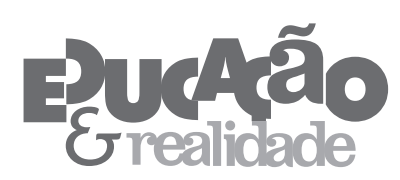

\author{
Marcelo Ricardo Pereira' \\ 'Universidade Federal de Minas Gerais (UFMG), Belo Horizonte/MG - Brasil
}

RESUMO - O Que Quer Uma Professora? Partindo da sugestiva e não menos polêmica interrogação de Freud, O que quer uma mulher? (já que supõe o desejo dela: o que ela quer?), problematizamos o gênero, a maternagem, a feminização histórica e cultural do magistério e o simulacro masculino dessa profissão. Seria procedente a tríade mãe-mulher-pedagogia? Para responder, procuramos assinalar equiparações e contrastes entre a psicanálise e as teorias de gênero, como também diferenciar conceitos nunca bem esclarecidos acerca do feminino, da sexualidade feminina e da feminilidade, sendo esta última uma condição comum a mulheres e homens. Em seguida, interrogamos a suposta misoginia freudiana ao levar às últimas consequências sua noção de falo, para então perceber o deslocamento que a narrativa dos professores apresenta ao evocar a condição feminina como quiçá originária e inventiva.

Palavras-chave: Psicanálise. Feminilidade. Gênero. Professor.

ABSTRACT - What Does A Teacher Want? From the evocative and controversial question of Freud, What does a woman want?, we discuss the gender, the motherhood, the feminization of teaching history and culture and the masculine simulacrum of the profession. Could it be the triad motherwoman-pedagogy? To answer, we seek equivalence point and contract between psychoanaliys and gender theories, as well as we differentiate the concepts of female, female sexuality and femininity. The latter is a common condition for women and men. Then, we question the supposed Freudian misogyny to explore the notion of phallus. To understand it, in the narrative of the teachers, the displacement of the female condition as originary and inventive.

Keywords: Psychoanalysis. Femininity. Gender. Teacher.

Educação \& Realidade, Porto Alegre, v. 39, n. 1, p. 181-199, jan./mar. 2014. 
O Que Quer Uma Professora?

Trazemos a público parte dos resultados de um amplo trabalho de investigação que contou com a participação de um número expressivo de professores, tanto da rede regular de ensino quanto da rede não regular, que inicialmente se sentiram motivados a narrar algo acerca da pergunta que atravessou nosso trabalho: por que os professores de hoje se dizem tão desautorizados? ${ }^{1}$

Entre os resultados revelados, percebemos que a problematização do gênero, da maternagem, da feminização histórica e cultural do magistério e do simulacro masculino da profissão é igualmente relevante quando se conjectura acerca dos impasses da autoridade docente de nossos dias. Tanto as teorizações de pensadores da educação, da sociologia, dos estudos culturais e da psicanálise quanto nossas análises das entrevistas de orientação clínica que realizamos com professores e professoras confirmam a fundamental necessidade de refletirmos e recolocarmos o tema. Essa problematização, própria de nossa contemporaneidade, é apenas a versão final de algo que vem revirando a suposta estabilidade ou fixação discursiva que as civilizações ocidentais conheceram até o início do século XIX. Desde então, a história parece estar agindo por saltos no que tange a certos aspectos do abalo da hegemonia masculina e da conquista feminina.

Mas essa equação entre o declínio do viril e a emancipação da mulher, entre a noção de profissão - que é essencialmente masculina e sua crescente feminização, tem sido algo difícil de resolver. O resultado imediato é bastante sensível para ambos os sexos, e em especial para as mulheres, que durante séculos viram seus gozos serem confinados ao perímetro da casa. Esse destino vem sendo bombardeado com êxitos e reveses desde o século XIX pelas próprias lutas feministas, em suas várias ondas; pela interrogação das tradições; pelo avanço de uma sociedade técnico-imagética frente à palavra; e pelo discurso capitalista e o mercado de trabalho, que as emancipou desse campo privado, mas sem deixar de aliená-las nos imperativos da produção. Ao lado disso, outra fonte de bombardeio foi a invenção da psicanálise que, como o feminismo, se consolidou reconhecendo o desejo e o poder da mulher. Aliás, a psicanálise e o feminismo gozam de um inquestionável emparelhamento histórico, ainda que nunca muito bem esclarecido. Ambos inquirem e ao mesmo tempo são testemunhas da derrocada de uma cultura patrilinear e vertical vigente até então; ambos quiseram, com efeito, dar nome ao desejo feminino.

A psicanálise nasce em fins dos oitocentos, desfazendo a fronteira entre normal e patológico e teorizando a existência de uma sexualidade da mulher e da criança, ao lado da do homem. Foi verdadeiramente um escândalo para moralistas, conservadores e mesmo cientistas da época. Já o feminismo, datado do mesmo período e também causador de escândalos similares, surge com as campanhas pelos direitos contratuais, civis, reprodutivos e sexuais, além da conquista do sufrágio, que eram, assim como a sexualidade, privilégios essencialmente masculinos. $\mathrm{Na}$ 
realidade, nossos tempos atuais ainda vivem sob o reflexo da enigmática pergunta freudiana "O que quer uma mulher?", que como tal supõe o desejo dela - o que ela quer? -, e ao mesmo tempo sob o reflexo de slogans feministas como "O pessoal é político", que convocaram o Ocidente a instituir políticas de identidade para além da supremacia identitária masculina. Com isso, a família, a patrilinearidade, a sexualidade, a noção estável de gênero e a divisão doméstica do trabalho ganharam o peso da contestação política. Com isso também, a maternagem, a feminização de várias profissões, a emancipação da mulher, muitas vezes falicizadas, ganharam tácita e visivelmente o cenário social.

\section{A Tríade Mãe-Mulher-Pedagogia}

O termo maternagem foi empregado, entre outros autores, por Eliane Lopes (1991) ao debater, com base na história e na psicanálise, a questão da feminização do magistério. Em outro trabalho, recuperamos tal debate para elucidá-lo e ampliá-lo. Com efeito, afirmamos que "o saber dos profissionais da educação parece privilegiar a experiência sem relacioná-la à epistéme ou aos campos de conhecimento que fundamentam a pedagogia" (Pereira, 2008, p. 173).

A preocupação estaria mais centrada em se ter um saber sobre o outro, em governá-lo, em ter um melhor convívio e um maior cuidado, que é caracterizado culturalmente como materno, fazendo com que esse discurso - o materno - embarace-se com o discurso profissional da pedagogia moderna. Ao que parece, a pedagogia se afasta muitas vezes da consolidação de um corpus epistemológico e não demonstra deter ou refrear a domesticidade, o que acarreta a si alguns prejuízos fundamentais.

O discernimento entre o materno e o pedagógico faz-se um tanto obscuro devido ao fato de que existem várias formas de se educar alguém. "O vigor do saber-fazer parece superar a mais forte das racionalidades ou epistemologias. A educação prescinde da academia" (Pereira, 2008, p. 176). Com o declínio contemporâneo da imago paterna, e não propriamente do valor fálico do pai, o discurso da maternagem passa a demandar o carimbo científico, sendo a pedagogia a materialização essencial para tal intuito. Várias mulheres se utilizam dela para tentar cientificizar seus saberes como mães ou futuras mães, fazendo com que o discurso pedagógico seja um espelhamento do discurso materno. Isso pode levar a um de seus prejuízos, qual seja, seu enfraquecimento político.

Sobre a problematização do gênero, partimos de pressupostos teóricos de Joan Scott, em seu marcante e repisado artigo Gênero: uma categoria útil de analise histórica (1990), Judith Butler, em seu referente Bodies that matter (1993), ainda sem tradução no Brasil, bem como de seus desdobramentos (Scott, 1994; 1998; Tilly, 1994; Varikas, 1994; Butler, 2003, 2006). Com base nesses trabalhos, notamos como essa cate-

Educação \& Realidade, Porto Alegre, v. 39, n. 1, p. 181-199, jan./mar. 2014. 183 
goria se constituiu, como se sedimentou e também como se deu o modo de seu funcionamento nas relações humanas, refletindo igualmente nas relações pedagógicas. Utilizado em princípio como um substituto do termo mulher, o termo gênero mostrou-se mais adequado, por sugerir que qualquer informação sobre as mulheres é também informação sobre os homens, ou seja, o estudo acerca de um implica o estudo acerca do outro, por ser a sede fundamental da alteridade. Além disso, o termo levou a cabo os esforços de politização da diferença dos sexos e de interrogação tanto do binarismo como da hierarquização dessa diferença (Butler, 2003). Decididamente, o uso do termo gênero teve a igual proposta de "designar as relações sociais entre os sexos", rejeitando explicações biológicas e se referindo à política ou "às origens exclusivamente sociais das identidades subjetivas de homens e de mulheres" (Scott, 1990, p. 75).

A autora critica o fato de não se atribuírem razões pelas quais as relações são construídas como sociais, sendo necessário que se pense sobre como elas funcionam ou como elas mudam em função de sua inserção na história. Nesse sentido, o próprio termo deve ser emparelhado à circunstância histórica em que ele se apresenta. Revendo e discutindo sua posição anterior, a mesma Joan Scott analisa: “[...] sou de opinião que talvez tenha chegado o momento, não de retirar o termo gênero, mas de insistir sobre a ideia de que esse termo possui uma história; é preciso historicizar o gênero" (1998, p. 122).

Entre os autores que utilizam o termo, com efeito, estão as historiadoras feministas. Existem basicamente três posições teóricas que tais historiadoras têm empregado em suas várias abordagens quanto à análise do gênero. A primeira tenta explicar as origens do patriarcado e do conservadorismo social dos tempos modernos; a segunda, de tradição marxista, busca o compromisso com as críticas feministas de cunho histórico e libertário; e a terceira, em que pretendemos nos deter, diz da inspiração em diferentes escolas de psicanálise, além de outras de referencial estruturalista e pós-estruturalista, como as da linguagem, para explicar a produção e a reprodução da identidade de gênero do sujeito contemporâneo.

Jacques Lacan aparece para as autoras feministas como figura central no contexto das teorias da linguagem. O sistema de significados para elas é essencial para se pensar as construções e associações que todos nós fazemos sobre feminino, masculino, relações de poder e valorações. As sociedades "[...] representam o gênero, servem-se dele para articular as regras de relações sociais ou para construir o significado da experiência. Sem significado, não há experiência; sem processo de significação, não há significado" (Scott, 1990, p. 82).

A linguagem, enquanto central na teoria lacaniana, diz a autora, é chave de acesso à ordem simbólica e é também através dela que uma identidade generificada é construída. Sendo o falo o significante central da diferença sexual - entendido de maneira metafórica - e a ameaça de 
castração o que coloca a criança em relação direta com o poder, com as regras da lei, tal relação irá depender de sua identificação imaginária (ou fantasística) com a masculinidade e a feminilidade. As formas como o masculino e o feminino estabelecem uma relação com o falo e com a castração são inteiramente diferentes. A identificação de gênero, mesmo parecendo ser fixa, é instável e se constitui como ponto fundamental para a teoria psicanalítica.

A ideia de masculinidade repousa na repressão necessária de aspectos femininos - do potencial do sujeito para a bissexualidade - e introduz o conflito na oposição entre o masculino e o feminino. Os desejos reprimidos estão presentes no inconsciente e constituem uma ameaça permanente para a estabilidade da identificação de gênero [...]. As ideias sobre o masculino e o feminino não são fixas, uma vez que elas variam de acordo com as utilizações contextuais (Mitchell; Rose, 1978 apud Scott, 1990, p. 82).

Para Scott, seguindo os pressupostos de Butler, tal teoria tem seus problemas por se fixar em questões individuais do sujeito e também por universalizar as categorias e as relações entre masculino e feminino, "não permitindo introduzir uma noção de especificidade e de variabilidade histórica”. E acrescenta: “[...] o falo é o único significante, e o processo de construção do sujeito generificado é, em ultima instância, previsível, já que é sempre o mesmo" (1990, p. 83).

Apesar de reconhecermos alguns elementos centrais dessa crítica, ainda assim julgamos pertinente examinar as falas dos professores com os quais estivemos para a pesquisa em referência, problematizando os pressupostos tanto da psicanálise quanto dos estudos de gênero. Em momento algum nos esquecemos de que tais dados devem ser pensados levando-se em consideração o caráter histórico que os constitui.

Com o intuito de desenvolver especulações sobre a desautorização e a subjetividade docentes, percebemos que houve alguma recorrência acerca de referências implícitas ou explicitas à dicotomia mulher-mãe ou até mesmo à tríade mulher-mãe-pedagogia. Apesar de tais alusões não serem em um número tão regular, achamos importante analisá-las porque forneceram material elucidativo sobre os próprios sujeitos e sobre a situação geral dos docentes no que concerne ao exercício de suas autoridades. Acreditamos ser a psicanálise um dispositivo eficiente, uma vez que ela tem como sua maior base de sustentação o discurso. É através dele que podemos acessar o mais singular no sujeito, isto é, sua divisão sexual - motivo fundamental da constituição do inconsciente -, como também acessar as marcas sociais e históricas que a caracterizam.

Inserindo uma questão de método, antes de evocarmos as contribuições da psicanálise acerca da constituição do sujeito, em especial, do feminino, julgamos necessário discorrer esquematicamente sobre diferenças e aproximações entre a pedagogia - forma aplicada da edu- 
cação - e a feminilidade propriamente dita - motivo de contradições no exercício da própria prática dos envolvidos. Isso nos ajudará a contextualizá-la.

Sabemos que anteriormente, até metade do século XIX, os professores, mestres, tutores, preceptores eram em sua grande maioria homens. Somente eles tinham acesso ao saber e, portanto, podiam transmiti-lo. O que estava reservado às mulheres dizia respeito a ofícios domésticos, como plantar, cozinhar, bordar, tecer, cantar e atividades internas ao lar. Toda educação propriamente intelectual lhe era em regra proibida. Nas camadas médias e ricas da população, as meninas, ainda crianças, eram enviadas aos conventos, onde aprenderiam o básico que uma mulher precisaria para ser boa esposa e dona de casa eficiente. Os meninos ficavam com os tutores e aprendiam a ler, escrever, alguma introdução ao latim, bem como oratória, geografia e história, tendo sua educação completada nos internatos quando se tornavam maiores de idade. E cabe sublinhar que isso ocorria sobremaneira em famílias mais abastadas (Badinter, 1980).

Desde esses tempos, as coisas mudaram. A pedagogia tornou-se, e ainda é hoje, um campo de atuação marcado predominantemente pela presença de mulheres. Eliane Lopes (1991) procura articular alguns pontos sobre essa questão, com o intuito de entender a feminização do magistério, e pergunta: por que as mulheres se tornam professoras ou têm se tornado professoras? O que essa profissão possui que as captura? Se, antes, somente os homens tinham tal acesso e, se agora, as mulheres não só ocupam a maioria dos espaços da área da educação, mas também são as grandes responsáveis por sua transmissão, o que elas trouxeram de novo à profissão?

No século XX, o trabalho extradomiciliar tornou-se parte inalienável na realização dos homens. $\mathrm{O}$ trabalho feminino refletia o mercado disponível a elas, e não uma escolha individual. As mulheres estavam onde se esperava encontrá-las. Era necessário que a mulher fosse encaminhada para determinadas carreiras adequadas ao sexo feminino, sem muitas barreiras que dificultassem o casamento. Sendo assim, as mulheres começaram a trabalhar como professoras, ou bem porque desejavam ascender socialmente, e um trabalho não manual era mais adequado, ou bem porque o cargo era desvalorizado, com baixos salários, mas com pouco tempo de serviço por dia, que lhes possibilitava dar atenção ao marido e aos filhos. Mesmo assim, importa ressaltar o que se pensava à época: “[...] o melhor era que não trabalhassem” (Pessanha, 1994, p. 37).

Diante desse contexto, as falas dos professores que entrevistamos aparentemente mostram que ainda hoje tanto a escola quanto o ofício da docência estão marcados por uma referência feminina ou que tem na mulher e na maternagem seu ponto de ancoragem. Essa referência é multifacetada e aparece, por exemplo, na forma de nostalgia de uma 
época em que a escola "era mãe" e hoje passa a "ser madrasta”, palavras de um professor do Ensino Médio da rede pública, que analisa:

[...] a escola não tem tempo para a questão do aluno, ela não tem tempo pra isso, são assim, minutos corridos, tempo corrido, tem de aprender, não importa. E hoje a escola perdeu mais a função ainda, porque se ela vem [da forma] de uma escola "mãe", hoje ela não preocupa mais com isso, principalmente a coordenação da escola. Hoje só está preocupada se o aluno está em sala.

De “mãe” a "madrasta”, a escola não demonstra perder sua referência feminina. Algo que colocaremos em questão adiante.

Surgiram ainda apontamentos que caracterizam a prática docente como essencialmente materna, a exemplo do que diz outra professora do Ensino Médio da rede particular: "Eu brinco demais com os meninos, eu brinco como eu brinco com meus filhos". A regularidade de discursos como tal recoloca explicitamente a referência docente na ordem do feminino, da mulher ou da mãe, conforme indica uma professora do Ensino Fundamental da rede pública:

Eu prefiro que [o aluno] conte pra mim pra eu tentar entrar com um lado de mãe, que eu acho que toda mulher tem... mas acima de tudo a não repressão. Escuto coisas dos meninos ali que eu acho que eles nunca contaram pra mãe. Talvez se eu tivesse um tempo maior com esses meninos, ou se eu pudesse depois do serviço trazer um pouquinho aqui pra casa, ia ser uma coisa muito bacana. Ia ser muito bacana, eu ia ser um ótimo apoio para eles.

As narrativas impõem aos sujeitos a crença de que a complexidade de ensinar está efetivamente ligada à função materna. Como já foi ressaltado, o saber-fazer materno é elevado em seu exercício ao nível do racional ou científico, sempre válido para aquele contexto específico e imediato. A relação professor-aluno parece estar pautada em um saber cotidiano afastado de uma epistéme, como se bastasse ser uma mãe esclarecida para saber lidar com esses "meninos" e ensinar-lhes algo. É difícil saber até que ponto isso serve como uma sombra ao impossível ato de educar ou se isso dificulta o desenvolvimento da pedagogia e o aperfeiçoamento da docência, mantendo-as fixadas a uma domesticidade que impede a consolidação de um corpus epistemológico.

Se até então ilustramos a questão com base na fala de professores que aproximam, sobremaneira, a maternagem ao ato pedagógico, há de se considerar, em contrapartida, a análise (e o desabafo) de outro professor do Ensino Médio de uma escola particular, que, mesmo sendo nostálgico, insere à questão algo diferente:

[...] com todas as pedagogas eu tive problema [...]. Sabe qual é a impressão que se dá? Que o pessoal que se formou em pedagogia é quem não gostava do jeito que era a escola, de jeito nenhum; quem não se deu bem na escola, quem tinha raiva da escola, e chegou lá querendo mudar tudo: mudar em termos de conteúdo, em termos de... aprendizagem, de exigência, mudar 
O Que Quer Uma Professora?

da água pro vinho, e pra pior, sabe? Cortar tudo, e falar não. É aquele famoso discurso: "não, o aluno também não aguenta ficar sentado o tempo todo". Uma coisa que acho que eles aprenderam muito erradamente foi que o aprendizado tem de ser sempre divertido, melhor dizendo, nunca pode ser com esforço... o aprendizado não vem de um esforço?

Essa relação mulher-mãe-pedagogia gera desdobramentos. Ainda hoje características de uma suposta personalidade feminina ou de um cuidado essencialmente materno se ligam à avaliação da prática dos envolvidos; e isso se faz muitas vezes sob um viés negativo que condiciona a complexidade de ensinar a uma visão por demais estereotipada. A maternagem parece compor a base genealógica do magistério contemporâneo. Nisso ele pouco se alterou. A constatação de que tantas referências apontadas pelos docentes levam em conta aspectos relacionados ao feminino e à maternagem faz supor que ambos estariam no lugar de um ideal de realização do magistério; ou, em outros termos, que o magistério seria o ideal de realização do feminino imbricado à ordem materna. Não podemos nos furtar à consideração de que ainda hoje algo da identidade da mulher, assim como da subjetividade de professoras e da constituição do feminino, esteja atrelado à maternagem, como bem nos mostraram algumas falas dos entrevistados com quem conversamos.

Mas é importante ponderar que a noção de maternagem, mesmo que lhe seja genealógica, não parece equacionar a questão da feminilidade em relação à subjetividade docente. A condição materna e a condição da mulher não deveriam se nivelar, mesmo que sejam comumente equiparadas e diferenciadas da condição masculina. Em geral, seguindo a narrativa dos professores, a mulher permanece sendo vista de forma passiva, com menor senso de justiça, mais débeis em seus interesses sociais e possuidoras de menor capacidade de sublimar suas paixões; em oposição aos homens, vistos como mais agressivos, mais ativos, com maior capacidade intelectual e racional - características histórica e diametralmente contrárias às das mulheres.

Essas deduções levam-nos a assinalar a importância de estudos que articulem a realidade prática à problematização de gênero, bem como à psicanálise. E, nesse sentido, concordamos mais uma vez com Eliane Lopes, que diz de maneira autoral: "A mim me parece que, ao se falar em professora, fala-se em mulher/feminino, mãe; não posso deixar de tentar ouvir a psicanálise" (1991, p. 34).

Passemos, pois, a analisar essas questões com base em tal dispositivo teórico-metodológico, não sem antes introduzir algum mote conceitual.

\section{“A Anatomia é Destino” e Não Origem}

Muito embora as classificações e representações que comumente se fazem sobre homens e mulheres sejam, com razão, diferentes, há 
algo desde Freud que os aproxima e os constitui em sua condição sexual: o falo. Esse é um termo caro à psicanálise. É bem verdade que Freud o emprega poucas vezes em sua obra, mas não podemos dizer o mesmo quanto à sua forma adjetivada. O termo fálico é largamente aplicado para introduzir uma noção nova que o faz afastar-se da matriz biológica: a de deslocar a primazia sexual do pênis ou da vagina, ao priorizar não a presença desses órgãos, mas a ausência, em especial a do pênis, sob a forma da castração. Nesse sentido, o falo não se reduz ao órgão masculino e, sim, à ambiguidade de sua presença, já que o impasse da castração para o sujeito é duvidar se o possui ou não. Ele então passa a ser o signo de uma ausência ou, mais precisamente, o signo de defesa contra essa ausência (Freud, 1924; 1931; 1933). Lacan (1958) revisou essa ideia freudiana, dando-lhe uma consistência decisiva: o falo é o significante que, ausente, representa desejo. Todo infante é confrontado com os movimentos e os desejos da mãe (ou de quem quer que cuide dele), que se constituem como um enigma para si. A operação que aglutina os enigmas da mãe para a criança, dando aos dois uma significação, é fálica, pois o falo aqui opera condensando tais enigmas.

Inicialmente, a criança institui-se como sendo o objeto mais importante no campo de desejo da mãe, acreditando ser justamente o que ela mais quer: o falo (signo do desejo). Em sua vivência, através das várias formas de frustração (Versagung), seja a do seio que lhe é precocemente tirado; da imposição do controle dos esfíncteres; da vontade nem sempre efetivada de estar perto da mãe, de não poder tê-la incondicionalmente; bem como de sua entrada na linguagem - representante maior da lei do pai, da lei do socius -, o pequeno sujeito é interditado. Em condição de desamparo fundamental, segundo Freud, ou em falta (falta-a-ser), segundo Lacan, há a percepção de que existe algo contra o qual a criança não consegue lutar e que está fora de seu alcance. Assim, apesar de se perceber importante, ela não é exclusiva e tal experiência é vivida com angústia; a angústia de não ser o falo materno.

A mãe, por sua vez, também é marcada pela significação fálica. Em alguns momentos, a criança é tomada como seu próprio falo; ou seja, como significante que é tanto do desejo (de a criança julgar que é o falo da mãe e da mãe de tomá-la como tal) quanto da falta (do impossível de isso se efetivar plenamente). Eis o que as mantém, como a todos nós, consecutivamente desejando. De maneira incondicional, a criança quer ser o que falta à mãe, ser o objeto de desejo dela. Posteriormente, com a experiência simbólica da linguagem e da sujeição às leis da cultura, há a percepção de que o falo é, simultaneamente, aquilo que a mãe deseja e aquilo que ela não tem, tampouco a criança. Logo, o falo aponta de maneira direta para uma incompletude, uma falta, um desamparo. Ele seria aquilo que ninguém tem, mas que todos querem; ou seria, na verdade, uma tentativa de defesa contra a castração. Dado que o falo é o que esconde a falta, seu refúgio, ele também vira o significante da falta, algo que precisa ser coberto e que dá a ideia de uma dicotomia.

Educação \& Realidade, Porto Alegre, v. 39, n. 1, p. 181-199, jan./mar. 2014.

Disponível em: <http://www.ufrgs.br/edu_realidade> 
O Que Quer Uma Professora?

Em outras palavras: o falo está no lugar da falta e é também o que nos lembra dela.

Para Lacan, a castração e o complexo de Édipo, importantes conceitos freudianos que dão nome à incompletude do sujeito, girariam em torno do que denomina "falo imaginário", ou seja, a idealização ou fantasia de saturação dessa incompletude. Já a diferença sexual, materialidade real da incompletude, giraria em torno do "falo simbólico", ou seja, do significante do desejo do outro, que, como significante, sempre representa uma ausência. É importante ressaltar que essa ascensão ao simbólico distancia definitivamente o sujeito do falo, isto é, o de ser o objeto de desejo da mãe.

Mas o falo, mesmo presente na constituição do menino e da menina, não continuaria sendo um significante exclusivamente masculino? Sim. A psicanálise não vai recorrer a sexualidades distintas ou a uma teoria dos gêneros para entender a constituição sexual do sujeito. Ela vai, antes, recorrer a uma matriz fundamental que traspassa o infantil e o adulto, o heterossexual e o homossexual, o homem e a mulher. Essa matriz é o falo, significante da presença-ausência, versão materializada da libido (termo em latim para desejo) ou do que se pode chamar o Eros da pulsão. Sobre isso, o próprio Freud nos orienta ao parecer responder diretamente aos feministas:

A vida sexual é denominada pela polaridade masculinofeminino; assim insinua-se a ideia de considerarmos a relação da libido com essa antítese. Não seria surpreendente se se verificasse ter cada sexualidade a sua libido especial apropriada para si [...] mas nada disso procede. Existe apenas uma libido, que tanto serve às funções sexuais masculinas, como às femininas. À libido como tal não podemos atribuir nenhum sexo. Se, consoante a convencional equação "atividade e masculinidade", nos inclinamos a qualificá-la como masculina, mesmo não esquecendo que ela engloba tendências com finalidade passiva. Mesmo assim, a justaposição "libido feminina" não tem qualquer justificação (Freud, 1933, p. 161).

Aqui temos uma polêmica ruidosa cuja tese é rechaçada de modo engajado pelos teóricos de gênero, pelos feministas e também por um número considerável de psicanalistas que são adeptos a críticas como, por exemplo, as de Melanie Klein. Trata-se, na realidade, da tese do monismo sexual. Não haveria uma libido feminina, mas tão-somente a masculina, que explicaria a constituição tanto das mulheres quanto dos homens como sujeitos de desejo. Provavelmente, o conservadorismo e a misoginia de Freud, ao lado de sua experiência e atitude clínica, conduziram sua pena a essa tese que teoricamente se justifica, ainda que reclame entendimento.

Se admitisse uma libido feminina, a psicanálise se nivelaria às teorias de gênero e incorreria no mesmo impasse: o de banir uma determinação exclusivamente biológica em troca de uma determinação 
exclusivamente cultural, que pretende desnaturalizar ao extremo a sexualidade humana ou dizer o quanto ela é reflexo massivo da biopolítica ou do poder sobre os corpos impelido pela biologia. Eis um impasse em que o pensamento freudiano se vê embaraçado: ou bem endossa a matriz biológica, que inicialmente o fundamenta, sendo por isso criticado pelos defensores do gênero; ou bem endossa a perspectiva culturalista, aderindo à cruzada histórica dos estudos feministas e de gênero que, mesmo sendo legítima, desviaria a psicanálise de sua posição original - a de operar na contramão de qualquer discurso determinista. É essa tensão que lhe está na origem: de um lado, por exemplo, a reativação da polaridade masculino-feminino, do outro, sua dissolução.

Talvez seja isso que nos permita ler melhor outro dos aforismos da psicanálise que ainda hoje causa animosidades, mesmos entre os pares: “a anatomia é destino”, disse Freud (1924, p. 222) em seu A dissolução do complexo de Édipo. Ela é destino e não origem. Ela é destino e não algo dado a priori ou determinado biologicamente. A anatomia é devir. É vir a ser. Em sua constituição, homens e mulheres buscam alcançar uma anatomia que nivele psiquismo e biologia, inscrevem seu desejo tentando emparelhá-lo ao seu corpo, mas o fazem em vão. É devido a isso que produzem sintoma, lapso, sonho... o inconsciente. Algo de si definitivamente excede tanto às determinações biológicas quanto às sociais. Freud sabia disso e não escondeu:

\begin{abstract}
Não devemos nos permitir ser desviados de tais conclusões pelas negações feministas [...], mas concordaremos de boa vontade que todos os indivíduos, em resultado de sua disposição bissexual e da herança cruzada, combinam em si características tanto masculinas quanto femininas, de maneira que a masculinidade e feminilidade puras permanecem sendo construções teóricas de conteúdo incerto (1925, p. 320).
\end{abstract}

Rememorando-nos de que para a psicanálise tanto homens quanto mulheres tem impulsos masculinos e femininos e que, no inconsciente, tais impulsos se derivam respectivamente da atividade e da passividade, Freud vai afirmar que, terminantemente, cada um dos sexos não pode ser equacionado de maneira exclusiva ao masculino e ao feminino, numa perspectiva cultural - de "conteúdo incerto" -, muito menos ao macho e à fêmea, numa perspectiva biológica - que não é mais do que devir ou "destino". Posto isso sob tensão, o pensamento freudiano constrói um elemento fora do corpo, presente e ausente, que signifique o desejo do sujeito às voltas com a castração simbólica: o falo. Esse significante não se encontra materializado nem no homem nem na mulher, porém é fato que o homem, que escreveu a história quase sozinho até o século XIX, acredita muito mais do que a mulher que ele é o possuidor do falo. Eis a sua ilusão que os séculos seguintes vieram a interrogar. Temos aí um dos méritos que comungariam as teorias de gênero e a psicanálise.

Educação \& Realidade, Porto Alegre, v. 39, n. 1, p. 181-199, jan./mar. 2014. 191 Disponível em: <http://www.ufrgs.br/edu_realidade> 
O Que Quer Uma Professora?

Por isso, achamos pouco profícua a precipitação militante de repisar a pessoalidade misógina de Freud ou de invocá-la como falocrata. Ora, não temos dúvida de que, ao longo de boa parte de seus trabalhos e teorizações, Freud manteve-se conservador, fiel à ordem iluminista herdada dos gregos antigos, que consideravam a sexualidade humana sob princípios eminentemente masculinos. Mas ao fazer vacilar a masculinidade, dizendo-a castrada, sem saber se possui ou não o falo, atropelada por um inconsciente bissexual, ele parece desprender-se acertadamente do iluminismo que o inspirou. Sabemos que Freud erra em muitos aspectos concernentes à abordagem da realidade concreta da sexualidade humana, sobretudo, a feminina. Como exemplo disso vale citar o modo com que toma a maternidade como a melhor saída, entre as tantas que assinalara, para o impasse que a feminilidade rendia à mulher de sua época. Entretanto, a nosso ver, a tese do monismo sexual, com base no falo, não se traduz propriamente num erro, ainda que tenha nascido da pessoalidade irrequieta e geniosa de seu autor. Se a história ainda não a suprimiu e a mantém polemizada, isso nos incita a revirá-la, sabendo que essa pessoalidade de Freud não pode ofuscar seu achado.

A tese diz que a sexualidade fora concebida a partir tão somente do operador fálico. Ele seria a condição própria de estruturação do erotismo. Mas o falo não se reduz ao pênis e, sim, à sua presença-ausência (ou presença de uma ausência), já que o complexo da castração é marcado pela dúvida. É a falta do pênis na mulher que revela a natureza do falo, diz Lacan (1965). Logo, ele é imaginariamente o que o pênis representa em nossa cultura: poder, saber, arrogância, suficiência, não precariedade. Tais insígnias criam a ilusão de uma sociedade do espetáculo (Debord, 1997), masculina por excelência. Homens e mulheres a querem e encenam-se sobre seu tablado. Para tanto há uma pregnância fálica no erotismo de ambos.

Porém, à revelia disso, existiriam no psiquismo pulsões sem representação que contestariam essa pregnância, não sendo a ela subordinadas. Temos então a primeira marca de revelação teórica do território da feminilidade. Esse território não seria nem fundado nem regulado pelo operador fálico. Não seria natureza, nem categoria, nem totalidade, nem gramática, mas pura ausência ou enigma.

Esse passo foi fundamental para que Lacan, em 1972-1973, polemizasse o aforismo "A mulher não existe", extraído das páginas de La Rochelle, e causador de arrepios entre feministas e teóricos de gênero. Na realidade, não existe uma universal da mulher ou, dito de outra forma, com Lacan, ela não está toda na ordem fálica, ela é não toda. Dada a sua condição feminina, ela escapa da ordem fálica por um gozo suplementar, ilimitado, sem representação e fronteiriço à morte - pulsão com a qual Freud desorganiza a gramática fálico-normativa.

Entretanto esse gozo ilimitado e sem representação causa horror tanto em homens quanto em mulheres. A isso Freud chama de repúdio 
à experiência da feminilidade pela ausência do falo. E devemos sublinhar: a feminilidade (Weiblichkeit) parece dizer de uma condição, e não propriamente de um gênero. Tal condição é comum a homens e mulheres e revela o mais além, vazio, fora da norma, ex nihilo. Ao formular isso, a psicanálise também anunciou que a feminilidade estaria na origem do psiquismo e cisão do eu, e não na sua recusa fálica. É, pois, esse horror à feminilidade ou à condição feminina - e não às mulheres - que nos levaria a bipolarizar e a hierarquizar os sexos. Aqui, esse raciocínio binário pode ser desconsiderado. Não há gênero em psicanálise, pois só há o falo - significante masculino da recusa da castração. Agora, sim, estamos em condição de afirmar que o falo é, com efeito, uma defesa; uma defesa contra a feminilidade.

Disso se deriva uma tese, no mínimo, intrigante, a ser explorada por Joel Birman (2000; 2001), Regina Néri (2005), Marcelo Pereira (2006; 2010) e alguns teóricos de gênero que admitem debates psicanalíticos. O falo, como defesa contra a feminilidade, é na verdade o que a regula como enigma, como ausência, como um não lugar da norma, que estaria no centro genealógico do erotismo do sujeito. Não obstante, a não inscrição da feminilidade na lógica fálica, além de causar horror a homens e mulheres por se sentirem incompletos, forneceria a eles e elas uma abertura maior ao novo ou à inventividade - pelo menos no nível da especulação e do conceito. No lugar da incompletude, da falta, da poesia e da diferença, poderiam abrir-se caminhos, sim, à singularidade e à invenção. Como afirma Birman (2000), na feminilidade os enunciados parciais e fragmentados se opõem à lógica universalista: “[...] a finitude e a incerteza humanas tomam corpo, colocando o sujeito em aberto em face ao seu fazer, o que evidencia sua impossibilidade de encontrar enunciados totalizantes" (p. 94). Contudo, na medida em que o apelo ao fálico não é ultrapassado, mantêm-se as ilusões totalizantes e homogêneas, e o sujeito que hoje observamos, cada vez mais centrado em si, tem horror à diferença, que pode expor e denunciar socialmente sua fragilidade e finitude.

Importa dizer que abordamos aqui a condição feminina e não a condição materna, pois elas não se nivelam. Devemos frisar que a colagem imaginária entre os lugares do materno e do feminino definitivamente não coincide. Contrariando o senso comum, o lugar materno é tido em psicanálise como um lugar essencialmente fálico, masculino em sua origem. Freud (1933) acreditava que a única saída positiva para a mulher era ter um filho ou tornar-se mulher sendo mãe; ao que Lacan (1972-1973) emenda: a mulher só existe toda como mãe. Isso é o mesmo que dizer: ela só existe toda na universal do significante fálico como mãe. Seguindo essas pistas, o que contribui para que a identidade da mulher fique atrelada à função da maternidade é o fato de ela não possuir um pênis-falo e equacioná-lo com o filho. Já discorremos sobre isso: de mulheres inferiorizadas, faltosas, incompletas, não toda, passam então a ser mães falicizadas. A maternagem, portanto, uma vez fálica, seria também uma defesa contra a feminilidade.

Educação \& Realidade, Porto Alegre, v. 39, n. 1, p. 181-199, jan./mar. 2014.

Disponível em: <http://www.ufrgs.br/edu_realidade> 
Mas devemos reafirmar: a noção de maternagem está longe de equacionar a questão da feminilidade. O impasse permanece. Regina Néri (2005) lembra que o texto freudiano traz também a ideia da transformação da feminilidade (Weiblichkeit) em um conceito eminentemente teórico, que se diferencia da expressão sexualidade feminina (weibliche Sexualität) e recoloca, com efeito, a problemática da castração. Enquanto sexualidade feminina, para Freud, corresponde à sexualidade da mulher, a feminilidade parece corresponder a uma condição comum a homens e mulheres, anterior ao falo, e ao mesmo tempo regulado por ele. Essa regulação é a sua defesa, lugar fundamental do simulacro masculino. Para elaborar tal condição feminina, ambos os sexos teriam de se confrontar com a feminilidade, ao terem de lidar com sua própria castração ou com o que em si é fundamentalmente feminino (weiblich).

Tudo isso nos faz aceitar a provocação pitoresca de Freud, que admite sua própria insuficiência sobre o assunto. Fazemo-la também a nossa: "Se vocês quiserem saber mais sobre a feminilidade interroguem suas próprias experiências de vida, enderecem-se aos poetas, ou então esperem que a ciência possa vos dar informações mais aprofundadas e coerentes" (1933, p. 165).

\section{A Weiblichkeit (feminilidade) nos induz ao plural}

Esse détour conceitual permite-nos agora passar ao que concluímos acerca da feminização do magistério, da maternagem, da feminilidade e do falo como defesa contra ela. Estamos seguros de que a lógica fálica também perpassa a relação que os professores estabelecem no interior de suas escolas. Muitos deles julgam ser referência totalizante para o aluno e, como vimos, querem levá-lo para casa; querem cuidar dele ou fazê-lo se esforçar para superar obstáculos e fracassos. A nosso ver, existem determinadas posições subjetivas dos professores que parecem se assentar nos modos de cuidado, próprio da ordem materna, e, ao mesmo tempo, na necessidade de restituírem a eles próprios o significante da completude, a saber, o significante fálico. A maternagem, assim, seria outro nome do falo.

Isso comumente se expressa no desejo de ser mestre. O que quer uma professora?, perguntamos. Supomos que muitas professoras (e também professores) esperam que seu aluno venha a suprir sua falta, que seja assim um aluno-falo, fazendo cessar seu próprio desamparo; e, ao mesmo tempo, que seja ele, pelo menos um pouco, um aluno-filho, um aluno que demande cuidados. Por sua vez, no reflexo do espelho, essas professoras e esses professores também tendem a se colocar enquanto falo para que seu aluno se identifique e queira ser como eles, ao mesmo tempo em que exercem os cuidados demandados. É bem verdade que existem várias maneiras de se colocar como objeto de desejo para o aluno. Acreditamos que uma dessas maneiras seja através 
da maternagem. Mas, em vez de se colocar o filho propriamente dito no lugar de falo, coloca-se, com efeito, o aluno. Essa inferência apenas reforça as teses de Freud sobre o tema, recolocando-as no universo educativo, no entanto, admitindo o debate que aqui empreendemos acerca das teorias de gênero e da psicanálise, podemos dar o passo seguinte.

Se a fala de uma professora anteriormente anunciada, que diz "eu prefiro que [o aluno] conte pra mim pra eu tentar entrar com um lado de mãe, que eu acho que toda mulher tem...”, ainda confirma a equiparação conceitual e empírica acerca das condições feminina e materna, poderíamos desconfiar de nossas interrogações sobre o deslocamento de posições discursivas que começamos examinar.

O mesmo se poderia dizer em relação a outro professor - do Ensino Médio de uma escola particular -, que parece insistir na estereotipia da supremacia fálico-masculina e na bipolaridade hierárquica entre masculino-superior e feminino-inferior. Ele considera os profissionais da pedagogia, em sua maioria mulheres, nivelados à espontaneidade, à fruição, à natureza, ao prazer e à passividade; em oposição aos homens, que seriam nivelados à racionalidade, ao trabalho, à atividade. Diz ele acerca do esforço necessário para que o aluno aprenda:

[...] às vezes, há um lado mais light, mas tem hora que não, tem hora que é pesado mesmo, tem de estudar, tem de esforçar. E aí eu acho que o pedagogo vem muito com essa noção de que o aprendizado tem de ser muito natural, tem de fluir. Não! Tem hora que se exige um esforço do aluno mesmo, não tem jeito, não tem como. E aí, muitas vezes, bati de frente com todas as coordenadoras com quem eu trabalhei, com todas as pedagogas eu tive problema.

Todavia ainda que sua fala remonte à fixidez discursiva, percebese que ela não deixa de consentir com uma vacilação: a atividade, o trabalho, o esforço não são exigidos todo o tempo, pois "às vezes, há um lado mais light", mas em outro momento "é pesado mesmo, tem de estudar". A certeza supostamente masculina não age em tempo integral; em nenhum instante foi dito que o aluno tem de se esforçar sempre, do ponto de vista da racionalidade, e que a supremacia fálico-masculina deve ininterruptamente prevalecer.

Deduzimos que essa hierarquia entre homens superiores e mulheres inferiores, essa supremacia fálico-masculina e essa equiparação entre mulher, mãe e docência não apenas se tornaram erodidas quanto têm sido cada vez mais improcedentes. Isso se reflete de maneira muito decisiva no depoimento de um professor de Ensino Fundamental de uma escola pública, que revela:

[...] acho que está arraigado na sociedade que a mulher tem o poder da casa e o homem acredita que tem o poder de fora. Ele manda em tudo, mas ele é sempre submisso à mulher, ele sempre tem de se ajoelhar ali, porque o mundo é cruel [conclui a entrevista de orientação clínica, rindo-se de maneira debochada]. 
O Que Quer Uma Professora?

Se aparentemente esse professor apenas confirma de modo invertido a hierarquia binária, dando agora à mulher-mãe a posição que outrora fora ocupada pelo homem, suas falas em momentos anteriores são no mínimo reveladoras de algo genuinamente novo. Examinando outras sessões de entrevistas que realizamos com esse mesmo professor, podemos extrair algo seminal, que nos orientou a pensar a suspensão da hierarquia de gênero, a feminilidade como enigma e o falo como defesa. Em sua fala, ele admitiu que a mulher, a "patroa", sempre mandou em sua vida, que sempre se deixou controlar. Foi levado ao magistério de maneira forçada pela ex-esposa e por uma diretora da escola em que primeiro trabalhou como professor. Ele acredita que a educação é coisa de mãe e a escola também. Em suas palavras: "Eu acho que o ensino, em si, é muito da ordem de ser mãe, de aconchegar o outro; eu só aprendo aquilo que me faz bem, o que não me faz bem eu não aprendo, por isso eu acho que a educação ainda tem muito a ver com a mãe, tem de ser mãezona, o professor". E revela também: "Sempre tive um receio da escola, sempre; eu sou um aluno ainda, muito ainda [...]. Eu sempre me escondo, é uma dificuldade que eu tenho de lidar com ela...”. Como se pode notar, escola, mulher e mãe parecem se embaraçar na fala desse professor, a ponto de refletir na história que ele próprio conta aos alunos, estrategicamente, sob a forma de novela, em capítulos, para que os mesmos sintam-se motivados em suas aulas. "A história é muito sedutora”, diz ele. Suas narrativas envolvem personagens como a mulher, o homem e o demônio. A cada dia, e improvisadamente, ele a conta um pouco mais:

É na hora, na hora, cada dia eu conto de uma forma, dou sempre uma sequência. Nem sei como. Aí eu jogo: 'Quem é mais inteligente, o homem ou a mulher?' Aí, vira um auê, vira uma votação. Vamos ver quem descobre, quem tem propostas, entre o demônio, a mulher e o homem; e eles têm de fazer a proposta, e o demônio acha uma maneira... de sempre querer ser a mulher; a mulher tem o poder, a força, e ela consegue manipular o demônio o tempo todo, e eles não acham... saída [...] na minha história, na minha história (sic).

Não é improvável admitir que esse professor encontra-se no epicentro do que, definitivamente, tanto as teorias de gênero como a psicanálise outorgaram ao sujeito contemporâneo: de um lado a interrogação da supremacia masculina e, do outro, o falo como defesa contra uma feminilidade originária. Isso o recoloca em um lugar peculiar de docência, própria de nossos tempos. Esse professor parece dizer que, ao construir uma história, que revela ser a sua ("na minha história, na minha história”), ele evoca o poder manipulador da mulher, que supostamente faria do homem um ser submisso, como ele mesmo julgou a si, mas às custas de emparelhá-la ao próprio demônio: avatar primordial do lugar de enigma. E aqui temos provavelmente o elemento clínico mais essencial de sua entrevista. Talvez ele requeira à sua história uma mulher (fálica ou materna) para manipular o demônio, que pode ser ele 
mesmo; ou talvez seja ela o próprio demônio, já que este "acha uma maneira de sempre querer ser a mulher...”. O fato é que parece não haver "saída" para a sua história e que sua suposta supremacia masculina ou fálica não demonstra ser suficiente para o "jogo" que ele mesmo cria. $\mathrm{O}$ que mais esperar de um enigmático demônio recolocado no seu exercício docente que faz repetir uma história de se deixar controlar pela mulher? Desse modo, o território de sua docência não seria exclusivamente nem mais fundado nem mais regulado pelo operador fálico, mas como resposta à condição feminina.

Voltando então à pergunta que orientou este trabalho: o que quer uma professora (ou um professor)? Ousemos responder com o que se ouve: que se tenha um falo, um aluno-falo ou uma posição fálica, como defesa, ali onde se tem apenas um enigma, uma ausência ou uma feminilidade originária.

Não desconsideramos que, de maneira geral, a opinião dos professores sobre a feminilidade e a masculinidade ainda aparece muitas vezes como estereotipada e pouco enigmática. Mas é interessante perceber que algo dessa opinião começa a se demover. Talvez tenhamos êxito em admitir na experiência, e não somente na construção teórica, a feminilidade (Weiblichkeit) como alteridade, anterior à ordem fálica ou anterior ao binarismo masculino-feminino, que considera hierarquicamente o feminino como negativo do masculino. Se alguns sujeitos da escola ainda confirmam certa falocracia masculina através do saber cientifico técnico-racionalista e da docilização materna, podemos perceber embrionariamente outros professores fazendo isso balançar, ao tomar a condição feminina (para além da maternagem) como algo que suscita o enigma, o imprevisível, a contingência.

Importa ressaltar que abordar a autoridade docente e o declínio do discurso do mestre contemporâneo não é algo sem complexidade. Isso também implica discutir questões fundamentais como feminilidade, masculinidade, maternagem, falo, inconsciente, ao lado de questões de gênero, de relações de poder, de ética e de novas formas de constituição do sujeito. A tentativa aqui foi a de lançar bases para que se apreendam através do próprio discurso dos professores formas de se discutir tais questões, sem cair no risco da manutenção de estereótipos que muitas vezes caracterizam modos de produção de conhecimento.

A condição feminina, como aqui investigada, induz ao plural. Isso de modo algum pode ser confundido com a adesão à pluralidade de masculinidades e de feminilidades, que tão somente reafirmaria o padrão opositor de gênero. Interessa-nos a própria estrutura vazia, não totalizante, anterior ao falicismo, que seria aberta à inventividade - mesmo a existência podendo depositar sua multiplicidade de sentidos para escapar do horror ao vazio de tal estrutura. Se couber algum indicativo, e não uma solução, já que não é disso que tratamos, que as escolas, os agentes formadores e o pensamento educacional evoquem a feminilidade, seu enigma e seus novos modos de saber. Se há um impossível 
no ato de educar, que se traduz aqui como o encontro com a condição feminina, talvez tenhamos melhores chances de criar o novo ou de nos sentirmos menos desautorizados ao não assegurar tanto o falo a todo custo, evitando a invenção (e a incerteza) que o vazio de tal condição nos impõe cotidianamente. Apenas quando admitirmos o imprevisível, o não inscrito, o não todo, poderemos admitir igualmente o desamparo fundamental para nós mesmos e para o outro; e daí, quem sabe, fazer alguma diferença.

Recebido em 11 de junho de 2012 Aprovado em 26 de setembro de 2012

\section{Nota}

1 Ver Acabou a Autoridade? Professor, subjetividade e sintoma, FinoTraço/Fapemig, 2011, de nossa autoria, que publica os resultados da pesquisa A subjetividade docente produzida em tempos de declínio do discurso do mestre, financiada pela Fapemig, CNPq e PRPq/UFMG. Essa pesquisa contou com depoimentos escritos de 46 professores e 24 entrevistas de orientação clínica (isto é, que também possuem o caráter de intervenção ou de pesquisa-ação).

\section{Referências}

BADINTER. Elisabeth. Um Amor Conquistado: o mito do amor materno. Rio de Janeiro: Nova Fronteira, 1980.

BIRMAN, Joel. Insuficientes, um Esforço a Mais para Sermos Irmãos. In: KEHL, Maria Rita (Org.). Função Fraterna. Rio de Janeiro: Relume Dumará, 2000. P. 171-207.

BIRMAN, Joel. Gramáticas do Erotismo: a feminilidade e as suas formas de subjetivação em psicanálise. Rio de Janeiro: Civilização Brasileira, 2001.

BUTLER, Judith. Bodies That Matter. London: Routledge, 1993.

BUTLER, Judith. Problema de Gênero: feminismo e subversão da identidade. Rio de Janeiro: Civilização Brasileira, 2003.

BUTLER, Judith. Deshacer el Género. Barcelona: Paidós, 2006.

DEBORD, Guy. A Sociedade do Espetáculo. Rio de Janeiro: Contraponto, 1997.

FREUD, Sigmund. A Dissolução do Complexo de Édipo. In: FREUD, Sigmund. Obras Psicológicas Completas de Sigmund Freud. Rio de Janeiro: Imago, 1980 [1924]. (Edição Standard Brasileira, 19).

FREUD, Sigmund. Algumas Consequências Psíquicas da Distinção Anatômica entre os Sexos. In: FREUD, Sigmund. Obras Psicológicas Completas de Sigmund Freud. Rio de Janeiro: Imago, 1980 [1925]. (Edição Standard Brasileira, 19).

FREUD, Sigmund. Sexualidade Feminina. In: FREUD, Sigmund. Obras Psicológicas Completas de Sigmund Freud. Rio de Janeiro: Imago, 1980 [1931]. (Edição Standard Brasileira, 21).

FREUD, Sigmund. Novas Conferências Introdutórias Sobre Psicanálise: Feminilidade. In: FREUD, Sigmund. Obras Psicológicas Completas de Sigmund Freud. Rio de Janeiro: Imago, 1980 [1933]. (Edição Standard Brasileira, 22). 
LACAN, Jacques. A Significação do Falo. Escritos. Rio de Janeiro: Zahar, 1998 [1958].

LACAN, Jacques. Ciência e Verdade. Escritos. Rio de Janeiro: Zahar, 1998 [1965].

LACAN, Jacques. O seminário. Livro 20: Mais, ainda. Rio de Janeiro: Zahar, 1985 [1972-1973].

LOPES, Eliane Marta Teixeira. A Educação da Mulher: a feminização do magistério. Teorias e Educação, Porto Alegre, n. 4, p. 22-40, 1991.

NÉRI, Regina. A Psicanálise e o Feminino: um horizonte da modernidade. Rio de Janeiro: Civilização Brasileira, 2005.

PEREIRA, Marcelo Ricardo. Isso Não é Próprio de uma Mocinha. In: FIGUEIREDO, Adriana (Org.). Professor, Profissão em 3 Tempos: gênero, saúde e saber docente. Ouro Preto: Ed. UFOP, 2006. P. 57-87.

PEREIRA, Marcelo Ricardo. A Impostura do Mestre. Belo Horizonte: Argvmentvm, 2008.

PEREIRA, Marcelo Ricardo. O Horror à Feminilidade. In: FAZENDO GÊNERO, 9, 2010, Florianópolis. Anais... Florianópolis: UFSC, 2010.

PESSANHA, Eurize C. Ascensão e Queda do Professor. São Paulo: Cortez, 1994.

SCOTT, Joan W. Gênero: uma categoria útil de análise histórica. Educação e Realidade, Porto Alegre, v. 16, n. 2, p. 5-22, jul./dez. 1990.

SCOTT, Joan W. Prefácio a "Gender and Politics of History". Cadernos Pagu, Campinas, n. 3, p. 11-27, 1994.

SCOTT, Joan W. Entrevista concedida a M. Grossi, M. L. Hellbron e C. Rial. Estudos Feministas, Florianópolis, n. 6, p. 4-15, 1998.

TILLY, Louise A. Gênero, História das Mulheres e História Social. Cadernos Pagu, Campinas, n. 3, p. 29-62, 1994.

VARIKAS, Eleni. Gênero, Experiência e Subjetividade. Cadernos Pagu, Campinas, n. 3, p. 63-84, 1994

Marcelo Ricardo Pereira é psicólogo, psicanalista, professor da Universidade Federal de Minas Gerais e da Linha de Pesquisa Psicologia, Psicanálise e Educação do Programa de Pós-Graduação em Educação da UFMG. Coordena a Seção MG do LEPSI (USP, UFMG) e é membro da Red INFEIES (América Latina e Espanha) e do GT Psicanálise, Infância e Educação da ANPEPP.

E-mail:mrp@fae.ufmg.br 